\title{
ロッキングプレートを用いた脛骨顆外反骨切り術による治療経験
}

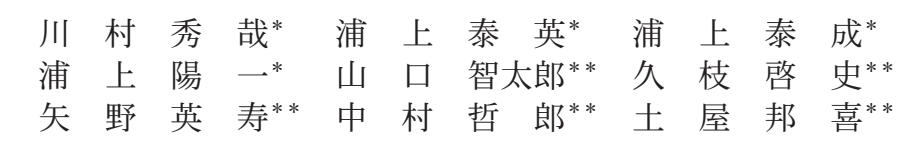

\section{Clinical Results of Tibia Condylar Valgus Osteotomy Using Locking Plate System}

\author{
Hideya Kawamura*, Yasuhide Urakami*, Yasunari Urakami*, \\ Youichi Urakami*, Tomotaro Yamaguchi**, Keiji Hisaeda**, \\ Hidetoshi Yano**, Tetsuro Nakamura**, and Kuniyoshi Tsuchiya**
}

\begin{abstract}
千葉は 1992 年, 新しい脛骨骨切り術として従来までの高位脛骨骨切り術の適応でなかつた内外反異常 動摇を呈する症例に対して脛骨顆外反骨切り術を発表した。現在では九州内の一部施設にて高度の変形性 膝関節症に用いられることもあるが，人工関節に比して必ずしもよい成績でなく，広くは用いられていな い. 筆者は骨切り適応年齢で内外反動摇の著しい例がよい適応であると考え, 2004 年より症例を選びロッ キングプレートを用いてこの手術を行つてきた。 今回, これらの症例の臨床評価を行い, 手術適応を考察 した。症例は 10 例, 11 膝であり，伸展位での X 線ストレス撮影で 5 ○上の外反動摇を呈し， かつ，関 節可動域の保たれた症例に行つた。人工関節適応の年齢については人工関節を忌避され，上記適応に準じ る希望者のみに行った. 術後約 3 年での術後成績は良好であり, 可動域も保たれており, 患者の満足度も 高かった.この術式は適応を限れば術後成績は良好であると思われた.
\end{abstract}

Chiba developed a new tibial osteotomy method in 1992 called it tibia condylar valgus osteotomy for patients with varus-valgus instability of the knee joint not indicated for conventional high tibial osteotomy. Some orthopedic surgeons in Kyushu use this method for patients indicated for arthroplasty of the knee joint. However, the results are not good compared with arthroplasty of the knee joint, so it is not used by most orthopedic surgeons. We attempted this osteotomy method for younger patients with varus-valgus instability of the knee joint indicated for conventional high tibial osteotomy, and performed it using locking plates. In this study, we investigated X-rays and clinical results of these patients to determine its usefulness.

We performed it on patients with over five degrees of valgus knee joint instability with good mobility of the knee joints. Ten patients and eleven knee joints were studied. Arthroplasty of the knee joint is usually indicated in elderly patients but since most dislike the procedure, patients with good mobility of the knee joint were selected in this study. Results at three years after the surgery were good. Good mobility of the knee joints was maintained, and the patients were satisfied with the surgery results. This method thus proved useful in the selected patients.

Key words : tibia condylar valgus osteotomy, TCVO (脛骨顆外反骨切り術), early weight bearing (早期荷重), internal fixation device（内固定材料）

$$
\text { は じめに }
$$

千葉は 1992 年新しい骨切り術として従来までの HTO の適応でなかった内側顆の骨摩耗, 欠損にて内
外反異常動摇を呈する症例に対して脛骨顆外反骨切り

術 (tibia condylar valgus osteotomy, 以下 TCVO) を発表した ${ }^{13)}$. 一部施設にて高度の変形性膝関節症全 般に用いられることもあるが，手術適応が曖昧であり，

\footnotetext{
* 医療法人しょうわ会正和中央病院整形外科 Department of Orthopaedic Surgery, Showa Medical Corporation Showa Chuo Hospital, Fukuoka, Japan

** 九州厚生年金病院整形外科 Department of Orthopaedic Surgery, Kyushu Kosei Nenkin Hospital, Fukuoka, Japan
} 
広くには用いられていない，筆者はこの術式は骨切り 適応年齢（有職者, 65 歳以下）で内外反動摇のある, HTO 適応外の症例がよい適応であると考え, 2004 年 より症例を選んでロッキングプレートを用い，この手 術を行ってきた. 今回, これらの症例の臨床評価を行 い, 手術適応を考察した。

\section{症例と評価方法}

症例は平成 16 年 7 月より 22 年 2 月までに九州厚生 年金病院及び当院にて TCVOを行った変形性膝関節 症 10 例，11膝である. 手術適応は術前診察にて徒手 的に内外反異常動摇があり, 膝伸展での X 線ストレ ス撮影にて 5 以上の外反動摇が認められた変形性膝 関節症，OA Grade（腰野）IIIないしIVであり，膝骨 壊死は適応外とした。ここでの計測は外反位 X 線よ り，内側の開き角を外反動摇とした。 65 歳以上では 人工関節置換術の適応であるが，人工関節を希望され ず (人工関節忌避例)，かつ，理解力があり，可動域 が温存され，筋力の保たれた症例を選んで行った. OA Grade (腰野) はIII $: 3$ 膝, IV : 8 膝であり, 手 術時年齢は $60 \sim 80$ 歳（平均 67.4 歳）であり，男性 3 例，女性 7 例であった。本来の適応症例は 6 例 7 膝で あり, 平均年齢は 62 歳, 人工関節忌避例は 5 例 5 膝 あり，平均年齢は 74 歳であった。術前関節可動域は 平均で伸展 $-4^{\circ}$, 屈曲 $140^{\circ}$ と良好であり, 術前 $\mathrm{JOA}$ Score は 55〜 90 点, 平均 66 点であった.

手術方法は関節鏡検査の後, 千葉1) の原法通り, 膝 内側に縦切開を加え， X 線透視下に脛骨内側顆にて 外側顆間隆起に向かう L 字状の骨切りを行い, 開大 器にて骨切り部を開き関節適合性が改善し, 内外反動 摇が消失した時点で内固定した。千葉 ${ }^{3)}$ と異なり，荷 重線の位置が外側顆中央付近を通ることは意図しなかっ た. Surfix Lock Plate System (SURFIX TECHNOLOGIES. France. 現在では国内発売中止) にて 7 膝，2009 年からは JUST FIT HTO Plate（ナカシ マメディカル製，販売（株）メディテック）を用いて 内固定した 。術後 $1 \sim 3$ 週より $1 / 3$ 部分荷重歩行を 許可し, $3 \sim 6$ 週にて 1 本杖歩行にて退院させた. 早 期退院希望者には可動可能な膝装具を作成し装着させ た. 希望者には転院治療を行った.

定期的な X 線撮影にて骨癒合，下肢アラインメン トを評価した，術後成績は直接の検診，または共同執
筆者による電話アンケートにより JOA Score にて評 価した.

結果

10 例 11 膝の術後経過期間は 8 ケ月から 6 年 3 ケ月, 平均 2 年 11 ケ月であった。術後経過にて骨癒合は順 調であり, 通常は術後 $3 \sim 4$ ケ月で癒合, 人工骨を移 植した 2 例では約 5 ケ月で X 線上骨癒合を認めた. 遷延癒合はなく, 経過中の矯正角度の変化はなく, 固 定材料の問題，折損，ゆるみや逸脱はなかつた．術後 最終経過観察時での立位荷重線の位置は内側より 34 〜105\%とばらついていた. 術後 JOA Score は 75〜 100 点であり, 平均は 87 点であった. 術後 3 年で脳 梗塞を発症し成績の低下した 1 例は成績評価から除外 したが, 脳梗塞発症までの成績は良好であった。術後 可動域は平均伸展 $-2^{\circ}$, 屈曲 $139^{\circ}$ であり, 術後一時 的に伸展障害が出現した 2 例も経過と共に改善してい た. 術後経過観察時には全例手術には満足されていた (図 1, 2).

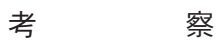

千葉は関節症 III, IVの症例の一部ではシーソー現象 により HTO 後も外側顆の適合が悪く，成績は不良で あるとして内側顆の摩耗した症例で関節適合性の悪い 症例に TCVO 適応があるとしているが, X 線学的定 量での適応の言及はない1). TCVOにおいても千葉は, HTO で緒方 ${ }^{8)}$ の勧めるような荷重線が外側関節の中 央付近を通るように矯正することを勧めているが ${ }^{3)}$, 内外反動摇以上の外反矯正を行うと ACL， PCL は過 緊張し内外側顆の荷重, 接触ストレスは増し, 変形の 増悪, 疼痛の増悪が推察される ${ }^{7}$. その ACL, PCL の緊張状態の把握, 術後矯正時の緊張状態の推察は術 前には困難であることが多く，一定以上の内外反動摇 のない症例での TCVO 時の外反矯正は危険性がある と思われる，従って今回，我々は可動域の保たれた膝 伸展時外反動摇 $5^{\circ}$ 以上の症例に限つて手術を行つた. 同時期に筆者が行つた人工膝関節は 524 例，高位脛骨 骨切り術は 196 例あり，いずれの治療成績も満足のい くものであり, TCVO 適応症例はかなり限られた. 今回の TCVO 症例では術後も可動域は保たれ, 術後 経過は良好であり，適応に誤りはなかったと思われる． 今回の評価は術後平均 3 年弱であり, 術後経過による 


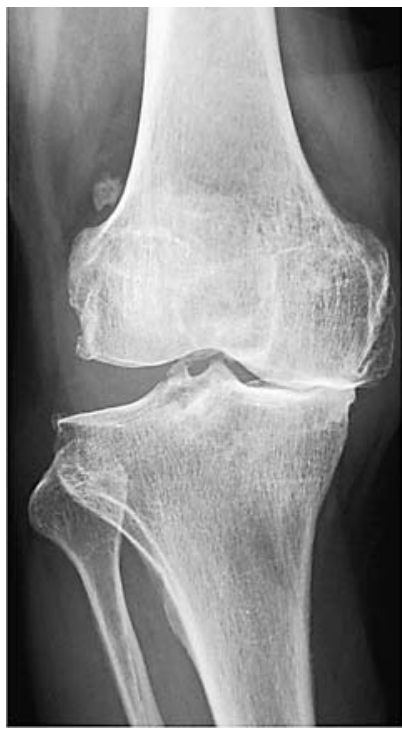

図 1-1

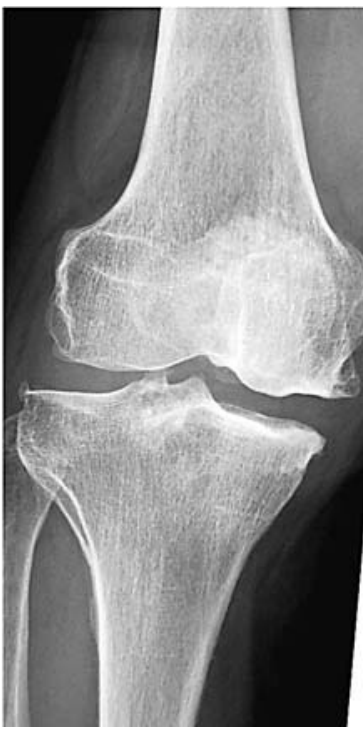

図 1-2

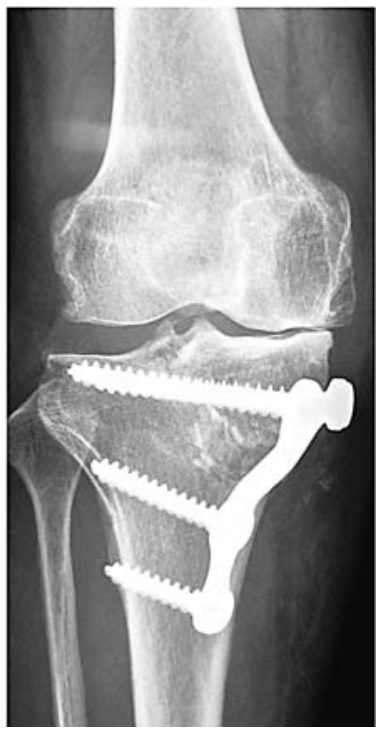

図 1-3

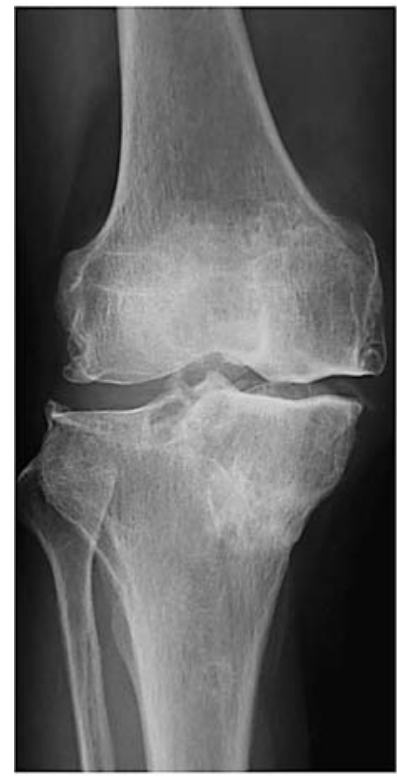

図 1-4

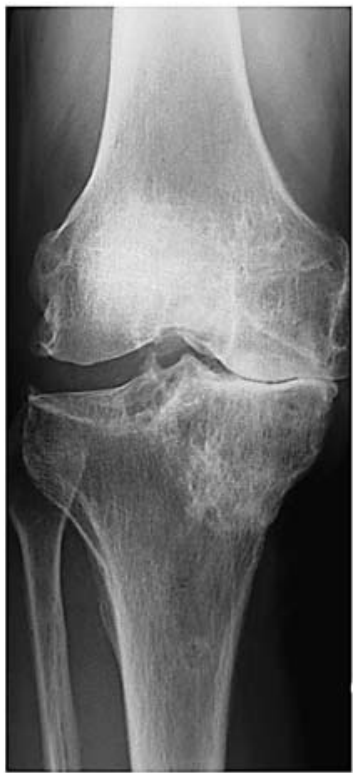

図 1-5

図 170 歳, 主婦. 術前 JOA Score 55 点. 内外反動摇が強く, 人工関節を嫌い, $\mathrm{TCVO}$ 第 1 例となる. 術後 6 年の現在, 屈曲は $135^{\circ}$ とわずかに悪化し, 正座困 難であるが, JOA Score 80 点と手術には満足されている.

図 1-1 術前立位ローゼンバーグ撮影

図 1-2 術前伸展外反位, $8 \circ$ の外反動摇あり

図 1-3 TCVO 術後 1 週

図 1-4 TCVO 術後 6 年, 臥位正面

図 1-5 TCVO 術後 6 年，立位ローゼンバーグ撮影

図 1-6 TCVO 術後 6 年, 全下肢立位正面

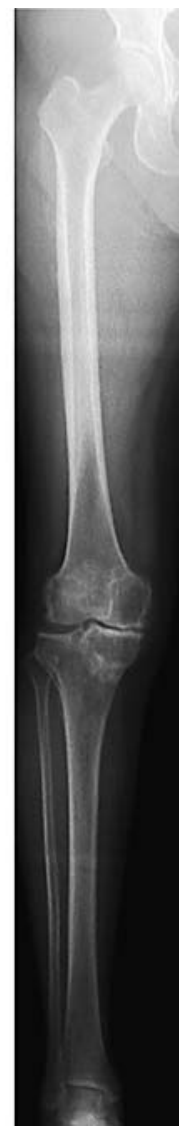




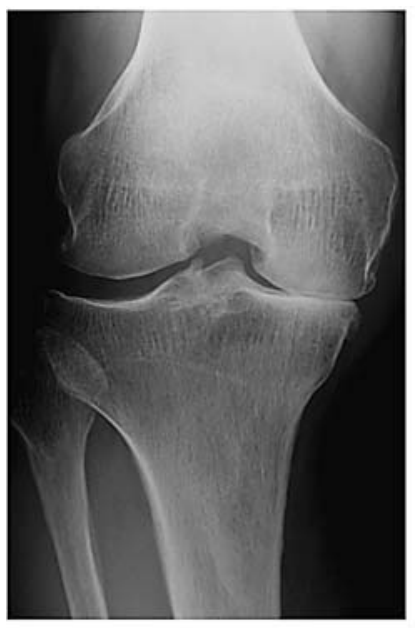

図 2-1

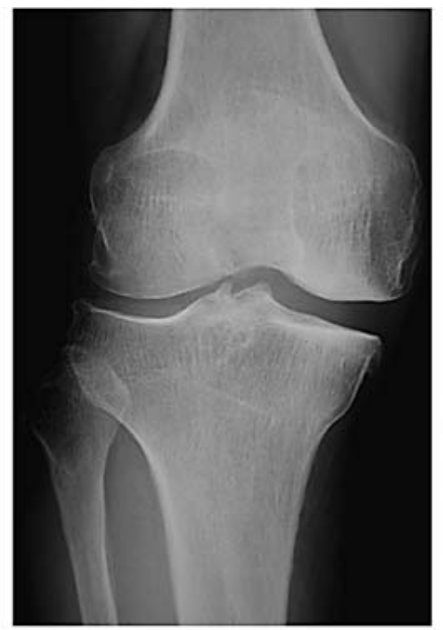

図 2-2

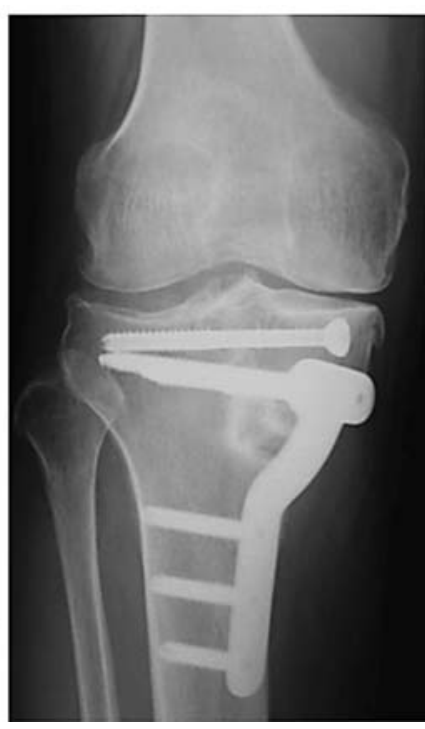

図 2-3

図 261 歳, 男性, クレーン車運転. 術前水腫を繰り返し, 徐々に悪化, JOA Score 65 点. 術後 3 ケ月で現職復帰, 仕事にも支障なく, 術後 1 年で JOA Score 95 点.

図 2-1 術前立位ローゼンバーグ撮影

図 2-2 術前伸展外反位, $5^{\circ}$ の外反動摇あり

図 2-3 TCVO 術後, 4 ケ月, すでに骨癒合している. 最近はこの JUST FIT Plate を用 い, プレート固定前にその近位を海綿骨螺子で締結固定している. 術後 1 週で部 分荷重歩行許可している.

成績の低下や長期成績の評価は出来ないが，適応を限つ て行われた今回の症例での短期治療成績は満足できる ものであった. 今後どれだけ長期間治療成績が保てる かは今後の課題であろう。筆者は他施設にて TCVO 後も疼痛が継続して減弱せず, 人工関節による再手術 を行つた数例を経験している.いづれも 70 歳以上の 高齢で変形が強く, 関節可動域は術前よりかなり制限 されており, 我々の適応から言えば適応外の症例であつ たと考えられる. 人工関節を忌避される患者のなかで, この術式が適応となる例はかなり限られると思われる. TCVO の成績不良例の報告も散見されるが(6)，手術方 法そのものの評価であり, 千葉以外には手術適応への 言及を述べた報告はない2)。我々の方法では術中の異 常動摇性がなくなる時点で矯正は終了するので術後矯 正肢位（荷重線の位置）を予測することはかなり困難 であり, かつ, 必ずしも荷重線の位置を外側には移動 できないこともあり, 荷重ストレスの分散による効果 は限られる. 仮に内反（荷重時）での外側の開き角を
考慮してこれに外反での開き角を合算して計測すれば 適応症例は増えると思われるが，中村ら ${ }^{7)}$ の提唱する open wedge HTO との併用がなければ, 矯正効果も 得られず，術後成績は低下することが危惧される。 た，今回の症例には純然たる MCL 不全の症例は含ま れておらず，陳旧性の MCL 損傷，MCL 不全が存在 する変形性膝関節症への適応は未確定であると思われ る.

今回の症例ではロッキングプレートを用いることに より比較的早期に荷重歩行を開始できた.この術式に おいて旧来の内固定材料ではかなり長期間，外固定や 部分荷重を余儀なくされていたので3)，ロッキングプ レートを用いることが出来るようになつて, 初めて筆 者もこの術式を採用した経緯がある．比較的自由に曲 げられ，HTOでも有用であった Surfix Lock Plate ${ }^{5)}$ が国内発売中止となり残念であるが，HTO 用に筆者 が開発した JUST FIT HTO Plate ${ }^{4)} も 十$ 分使用に耐 えうるものであった. この Plate はより強固に固定で 
き, 骨移植時にも強度は十分であり, 今後部分荷重の 時期をより早めることは可能であると思われた. 今回 の調査により TCVO においても HTO と同様にロッ キングプレートを用いることで, 術後在院日数の退縮, 早期社会復帰，安定した術後成績が期待されることが 確認できた.

\section{参 考 文 献}

1）千葉剛次：変形性滕関節症に対する脛骨顆外反骨切り 術. OS NOW, $13: 159-166,1994$.

2）千葉剛次：脛骨顆外反骨切り術の問題点と適応の限界. 日整会誌, 69(2) (3)：S592，1995.

3）千葉剛次, 進藤裕幸：変形性膝関節症に対する関節温 存療法 脛骨顆外反骨切り術。関節外科, 22 (6) : 74-85,
2003.

4) 川村秀哉：変形性膝関節症に対する膝骨切り術（プレー 卜固定を用いた楔状骨切り)。整形外科手術テクニック 膝関節編，pp.3-11. 王寺享弘編，大阪，メディカ出版， 2011.

5）川村秀哉ほか：Surfix Lock Plate を用いた HTO の 合併症とその対策. 膝，31(1)：58-62, 2006.

6) 北原博之ほか：当院における脛骨顆外反骨切り術の成 績と 2 例の成績不良例の検討。整外之災外，55：503507, 2006.

7) 中村 智ほか：内側型変形性膝関節症に対する脛骨顆 外反骨切り術に対する工夫. 整外と災外， $52: 540-544$, 2003.

8) Ogata, K.: Standing radiographs cannot determine correction in high tibial osteotomy. J. Bone Joint Surg., 73-B : 927-931, 1991. 